\author{
Juljan Jachovic ${ }^{*}$ \\ Institute of International Relations and Political Science, Vilnius University
}

\title{
The Reconstruction of Belarusian Identity Narratives: The Belarusian Language
}

\begin{abstract}
Since the beginning of Alexander Lukashenko's presidency, the Belarusian authorities' attitude towards the Belarusian language was seen as rather negative. However, amid turbulent events in the region, the official narratives on Belarusian statehood changed in 2014 with the rise of the so-called soft-Belarusization phenomenon. A new political discourse - positive towards formerly distinct opposition symbols, particularly the Belarusian language, was adopted by a number of different-rank government officials. Furthermore, it has been accompanied by a number of practical changes in government and civil society operations within an identity-building domain. This paper presents the results of a critical discourse analysis of the newly formed social representation reshaping the role of the Belarusian language, and the overall cognition of Belarusianness.
\end{abstract}

\section{Introduction}

Who are Belarusians? This is a question which requires, but does not have, a simple answer. Not just because the national identity analysis is a complex field of study, but also because of historical statehood struggles of Belarus that could be described as a path full of hardship, uneven cultural and linguistic developments, and political turbulence.

The Belarusian identity development under the presidency of Alexander Lukashenko, the first and thus far the only president of modern Belarus, will be analysed. The reader should note that there was a romantic period of the Belarusian cultural and linguistic revival in the early 1920s - also known as korenizatsiia - in the Eastern part of the modern Belarus territory. However, the policy of repression against the Belarusian intelligentsia and decades of successful Russification and Sovietization of the Belarusian society had followed. After regaining independence in 1991, the self-consciousness of the majority of the Belarusians contradicted the current time's reality. Larissa Titarenko, citing the VTsIOM survey of March 1991, highlights that only a quarter of Be-

\footnotetext{
* Juljan Jachovič is a PhD candidate of the Institute of International Relations and Political Science, Vilnius University. Address for correspondence: Vokiečių 10, LT-01130 Vilnius, Lithuania; tel. +370 52514130 , e-mail: juljan@jachovic.com
}

DOI: 10.2478/lasr-2019-0011

(C) Juljan Jachovič, 2019

(C) Military Academy of Lithuania, 2019 
larusians held a nationally oriented mentality while 69 per cent of Belarusians identified themselves as Soviet citizens. ${ }^{1}$ The independent survey conducted in 1993 demonstrated that only 22.3 per cent of Belarusians resented the re-creation of the USSR. ${ }^{2}$ According to the 1999 census data, only 36.7 per cent spoke the Belarusian language at home. ${ }^{3}$ Unsurprisingly, the national movements mainly focused on the Belarusian language agenda, but they - and the Belarus Popular Front in particular - did not gain massive public support in the 1990s.

Since 1994 both the authorities' policy and discourse towards the Belarusian language have been negative. Soon after the 1994 presidential election, Lukashenko launched ideological developments in the country that facilitated the de-Belarusification of the nation. In 1995 Lukashenko initiated the plebiscite through which the state language status was granted to the Russian language. In 2013, Belarusian scholar Vadzim Smok concluded that the Belarusian language "exists in a highly unfavourable, even hostile, environment" while most of the nation "follow the example established by the ruling elite." ${ }^{3}$ What was that example? Back in 1994, Lukashenko undermined the Belarusian language by saying that "nothing glorious can be expressed in Belarusian," and claiming that "the Belarusian language is a poor language. Only two great languages exist in the world - Russian and English." ${ }^{5}$ Such a perception of the Belarusian language and the aforementioned policy developments resulted in the decrease of the number of schoolchildren studying in the Belarusian language: from 40 per cent in 1994-1995 the number declined to 26 per cent in ten years. ${ }^{6}$ Under Lukashenko, the Belarusian language has not played any specific role - the Russian language was perceived as an official political and cultural language, while Belarusian was the language of the opposition; promoted by authorities, bilingualism was "a part of his [Lukashenko's] general strategy to return to the 'good old Soviet times."'

\footnotetext{
${ }^{1}$ Titarenko L. (2007), "Post-soviet national identity: Belarusian approaches and paradoxes", Filosofija. Sociologija 18(4), pp. 85-86.

${ }^{2}$ Независимый институт социально-экономических и политических исследований (2013),

“Геополитическое затишье”, http://www.iiseps.org/analitica/543, 18 January 2015.

${ }^{3}$ Национальный статистический комитет Республики Беларусь (1999), “Распределение населения Республики Беларусь по национальностям и языкам в 1999 году”, http://www.belstat.gov.by/informatsiya-dlya-respondenta/perepis-naseleniya/perepis-naseleniya-1999-goda/tablichnye-dannye/raspredelenie-naseleniya-respubliki-belarus-po-natsionalnostyam-i-yazykam-v-1999-godu/, 24 May 2019. ${ }^{4}$ Smok V. (2013), "Belarusian identity: the impact of Lukashenka's rule", Ostrogorski Centre, Belarus Digest, Analytical Paper 3, p. 15.

5 Лента.pу (2006), “Лукашенко решил переписать правила белорусского языка”, https://lenta.ru/ news/2006/08/30/language/, 24 April 2019.

${ }^{6}$ Спасюк Е. (2015), “Национальное сознание белорусов крепят на советском фундаменте.” «Белорусские новости», http://naviny.by/rubrics/politic/2015/02/20/ic_articles_112_188282/, 22 February 2015.

${ }^{7}$ Bekus N. (2014), “'Hybrid' Linguistic Identity of Post-Soviet Belarus”, Journal on Ethnopolitics and Minority Issues in Europe, 13(4), pp. 26-27, 34.
} 
The authorities' ideological efforts focused on building the so-called civic identity model, which diminishes ethnocultural elements of identity, such as national language or ethnicity. This strongly affected the society's self-identification and facilitated the rejection of the ethno-national identity model, ${ }^{8}$ which further was mainly endorsed by the opposition and civil society activists. Lukashenko initiated a row of reforms drawing Belarus away from ethno-national identity, including the replacement of the Belarusian coat of arms (Pahonia) and the white-red-white flag, referring to the Belarusian People's Republic, to slightly modified Soviet-era symbols. Independence Day was shifted to 3 July, the day of the "liberation of Minsk by Soviets." In turn, there is the coexistence of different identity projects in a single country, which were analysed by Nelly Bekus in her book Struggle Over Identity: The Official and the Alternative "Belarusianness".

However, in 2014 amid turbulent events in Ukraine, the official government narratives on Belarusian statehood, and the Belarusian language in particular, changed and sparked the discussion about the emergence of the so-called soft-Belarusization phenomenon, a process, when the new boost to the Belarusianness was given in the cultural field. The official attitude towards the Belarusian language has changed and the line between the aforementioned civic and alternative Belarusianness became more blurred.

Further, in this paper, utilizing the major principles of critical discourse analysis (CDA), I will analyse a newly formed social representation (a set of narratives, ideas) in relation to the Belarusian language. The analysis of changing narratives in this domain focuses on the particular group of high-ranking officials led by President Lukashenko in order to explore whether and how the state officials attempt to reconstitute the official cognition of Belarusianness and imply changes to the previously constructed identity model.

\section{Identity, Discourse and Social Representations}

A national identity is a phenomenon which is hard to conceptualize and, accordingly, analyse, because different authors refer and highlight different aspects of this research object. In this paper, I refer to Montserrat Guibernau and her concept of the nation and national identity, which provides a definition capturing the psychological aspect of the latter. Guibernau sees an

\footnotetext{
${ }^{8}$ Smok (2013), p. 19.

${ }^{9}$ Bekus N. (2010), Struggle Over Identity: The Official and the Alternative "Belarusianness", Budapest: Central European University Press.
} 
identity as a modern and dynamic phenomenon, when members of the particular community share a subjective belief that they are interconnected by cultural, historical, language, religious, statehood or other bonds, regardless of having a formal state. ${ }^{10}$ Guibernau points to five dimensions that constitute the national identity: psychological, cultural, historical, territorial and political. ${ }^{11}$ The framework of this analysis was structured to review first, and primarily, the cultural dimension and the Belarusian language in particular as the core element of this dimension. The discourse shift is the most observable in this dimension, and it sparked discussions on the soft-Belarusization trend. The other four dimensions were included in the analysis to a limited extent to see whether and how they are addressed within a period of emergence of soft-Belarusization.

The term social representation is used in this paper to conceptualize a set of ideas, narratives in relation to one or another identity element within the aforementioned five dimensions. A social representation is understood as a collective phenomenon aimed at forming or reconstructing the social object (in analysed case - the Belarusian language) within a certain social group (in this article - the authorities) to outline communication and action frames. ${ }^{12}$ Social representations have a dialectical relationship with social groups and, importantly, their identities. According to Serge Moscovici, the founder of the social representations theory, representations can form even a nation's selfconsciousness. ${ }^{13}$ But social representations are not equal to identities, they should be seen and analysed as smaller units that constitute meanings of different identity elements, which serve as a handful concept to organize a set of narratives and ideas concerning one or another identity element.

Besides identity construction, according to Caroline Howarth, social representations form the behaviour of social groups. ${ }^{14}$ According to Gerard Duveen and Barbara Lloyd, social representations are being recreated in interactions of the affected group, including in their communication and mass media. ${ }^{15}$ The life of social representations and their interaction with identity is

\footnotetext{
${ }^{10}$ Guibernau M. (2004), "Anthony D. Smith on nations and national identity: a critical assessment”, Nations and Nationalism, 10 (1/2), pp. 134-135.

${ }^{11}$ Ibidem, pp. 135-140.

${ }^{12}$ Wagner, W., Duveen, G., Farr, R., Jovchelovitch, S., Lorenzi-Cioldi, F., Marková, I. and Rose, D. (2002),

"Theory and method of social representations", Asian Journal of Social Psychology, 2(1), p. 96.

${ }^{13}$ Moscovici S. (1988), "Notes towards a description of social representations", European Journal of Social Psychology, 18(3), p. 228.

${ }^{14}$ Howarth C. (2006), "A social representation is not a quiet thing: Exploring the critical potential of social representation theory”, British Journal of Social Psychology, 45(1), pp. 73-74.

${ }^{15}$ Duveen G., Lloyd B., (1990) “Social representations as a genetic theory”. In S. Moscovici, S. Jovchelovitch, B. Wagoner (Eds.) Development as a Social Process: Contributions of Gerard Duveen, London: Routlege, pp. 177-180.
} 
cyclic. ${ }^{16}$ They appear within certain group pursuing own interests and sharing own identity, later they are constituted or reconstructed in the discourse and reflected in social practices. Once social representation is established, it begins to change an identity itself and dictate a social group's behaviour.

As Belarus' case demonstrates, the change in the perception of the language appeared first of all in the discourse formed by Lukashenko, the man whose words serve as guidance for the entire power vertical and are transmitted widely using conventional media channels owned by the state. To analyse a discursive change stemming from those in power, basic principles of CDA were employed. Although CDA features a variety of different approaches, the majority of them commonly stress the necessity to focus on the context of discourses, particularly the interrelation of analysed text with other texts and existing discourses, ${ }^{17}$ as well as socio-political and historical developments. ${ }^{18}$ Accordingly, the empirical part of this paper focuses on the authorities' communications, trying to distinguish the main narratives and explain them given the past record and their context in terms of that time political particularities and social developments, including narrative interrelation with other narratives both within the same communicative event (intertextuality - interrelation between language issue narratives of the cultural dimension) and the overall sample of speeches (interdiscursivity - interaction of the aforementioned identity dimensions with the cultural dimension, language issue discourse).

The sample of analysis included twenty-nine communicative events of Alexander Lukashenko (annual appeals, press conferences, meetings with media, media reports) that were either mentioning the Belarusian language topic (the major criteria) or novelly addressing other identity narrative, within a timeframe of the emergence of soft-Belarusization (since January 2014) up to April 2019. The priority was given to written texts in Russian or Belarusian language to capture the narratives and ideas that authorities addressed to the domestic public rather than the foreign audience. Segments of each text (sentences and/or entire paragraphs) were analysed thematically and coded (traced) using MAXQDA software. The following general codes that correspond to the aforementioned identity dimensions were identified during the thematic analysis:

\footnotetext{
${ }^{16}$ Wagner et al. (2002), p. 98.

${ }^{17}$ Wodak R., Meyer M., (2001) “Critical discourse analysis: history, agenda, theory, and methodology”, https://www.corwin.com/sites/default/files/upm-binaries/24615_01_Wodak_Ch_01.pdf

${ }_{18}$ Wodak R., (2002) "Aspects of critical discourse analysis", http://citeseerx.ist.psu.edu/viewdoc/download? doi $=10.1 .1 .121 .1792 \& r e p=$ rep $1 \&$ type $=$ pdf
} 
Table 1. Matrix of general codes and subcodes

\begin{tabular}{|lll|}
\hline Code & $\begin{array}{l}\text { Number of general } \\
\text { codes }\end{array}$ & $\begin{array}{l}\text { Total number of codes, } \\
\text { including subcodes }\end{array}$ \\
\hline Cultural dimension: & 6 & 6 \\
\hline Religion & 24 & 49 \\
\hline Perception of the Russian language & 31 & 74 \\
\hline Perception of the Belarusian language & & 10 \\
\hline Political dimension: & 10 & 89 \\
\hline Relation to the West & 43 & 7 \\
\hline Relation to Russia & 7 & 6 \\
\hline Relations with Ukraine & 6 & 2 \\
\hline Economic model & 2 & \\
\hline Political system model & & 8 \\
\hline Historical dimension: & 8 & 12 \\
\hline Statehood & 12 & 1 \\
\hline Relation to BNR & 1 & 12 \\
\hline Relation to GDL & 12 \\
\hline Relation to USSR & 23 & 53 \\
\hline Psychological dimension: & & \\
\hline Values of the nation & 28 & \\
\hline Territorial dimension: & & \\
\hline Territorial integrity and ethnicity & & \\
\hline
\end{tabular}

After texts were segmented into general categories, the repetitive narratives within these were distinguished and added as subcodes (narratives that convey specific ideas about the general code). This allowed to assess the aforementioned intertextuality and interdiscursivity in a quantitative way. In total, 378 general codes and subcodes were assigned to the analysed sample of text. In the last part of the analysis, the dialectical relationship between the newly constructed discourse on the Belarusian language and social practices was assessed by discussing practical developments (the practical context) accompanying the new social representation. 


\section{Changes in the Cultural Dimension}

\subsection{Signifying the role of the Belarusian language}

Unlike before the appearance of the soft-Belarusization trend, the overwhelming majority of Lukashenko's recent messages became highly supportive of the Belarusian language. Such a position was consistent throughout the last five years and significantly differed from the discourse prevailing before events in Ukraine in 2014, especially compared to the 1990s. Among the sample of Lukashenko's speeches, thirty-one messages (general codes) were related to the Belarusian language and its role in identity formation; forty-three specific subcodes were assigned to messages within that group of generic codes to identify common patterns discussed in this section below.

In 2014, Lukashenko delivered his official Independence Day speech in the Belarusian language, which was seen as an unprecedented act and sparked political discussion about the "return" to the Belarusian language on the highest official level. Already months before that, when delivering an annual appeal to the people and the parliament, Lukashenko had begun forming a set of new narratives to introduce the idea that the Belarusian language is one of the major features, as well as important heritage, of Belarus as a nation. This new role assigned to the Belarusian language was consistently maintained in the future, as it was recorded in twelve instances within an analysed sample of communicative events.

If we forgethow to speak the Belarusianlanguage-wewillstopbeing a nation. ${ }^{19}$ (April2014)

If you are the nation, you must have a language, your own language..$^{20}$ (March 2019)

Lukashenko scarcely but consistently was stressing the significance of the Belarusian language for identity formation, but particularly one aspect is important to highlight: Lukashenko began to use the Belarusian language for the purpose of distinguishing Belarusians from Russians, from the Russian Federation - the country Belarus is so closely associated within many of crucial for sovereignty spheres, starting from military cooperation and location of military facilities on the country's territory, ending with energy, economic and other asymmetric interdependence.

And I support the Belarusian language. Why, because this is what distinguishes us, for example, from Russian people, from Russians. This is the sign of the na-

\footnotetext{
${ }^{19}$ Официальный интернет-портал Президента Республики Беларусь (2014), “Послание Президента белорусскому народу и Национальному собранию”.

${ }^{20}$ Официальный интернет-портал Президента Республики Беларусь (2019), “Послание белорусскому народу и Национальному собранию".
} 
tion: if you don't have these particularities, your Belarusian language, but let's say, have only Russian, - this means you don't have this feature, and you are simply a Russian person, you are Russian. But we are Belarusians. ${ }^{21}$ (January 2015) Of course, language - this is the first, perhaps the only thing which distinguishes us from Russians and others. This is the sign of any nation. ${ }^{22}$ (March 2019)

In addition, Lukashenko hinted in his speech that the Belarusian language, which he made clear is the primary feature of Belarusian identity, cannot be given up in the face of economic pressure from Russia, which could be imposed, first of all, in the provision or deny of intergovernmental and specifically Eurasian loans, which also became a matter of negotiations in 2016.

[...] I don't want to lose this wealth, this heritage, this is worth much more than any credits or billions. ${ }^{23}$ (January 2015)

Although Lukashenko was not extensively elaborating on the new role of the Belarusian language, even these few ideas of a newly formed social representation on the Belarusian language gave an impetus to its perception in the country, especially among the social group Lukashenko belongs to - highranking state officials. They began to maintain the set of ideas sketched by $\mathrm{Lu}-$ kashenko. The officials did not hesitate or even felt incentivized to speak in the Belarusian language in public, including Prime Minister Sergey Rumas, Sports Minister Sergey Kovalchuk, in that time Deputy Prime Minister Mikhail Rusy, former Information Minister Lilia Ananich, and others. In addition, they reiterated the narratives of the Belarusian language becoming the unique feature of Belarusianness and an element, distinguishing Belarusians from Russians:

It would be terrible to lose the Belarusian language. How then we differ from our neighbours? ${ }^{24}$ (Vice Prime Minister, October 2014)

We have to speak Belarusian more often. [...] If you are Belarusian, if you understand that the country cannot exist without the language $[\ldots]^{25}$ (Foreign Minister, June 2017) Why we should not wear our national clothes, should not speak the Belarusian language? These are normal things, and I don't see any problems in that. ${ }^{26}$ (Foreign Minister, September 2018)

\footnotetext{
${ }^{21}$ Официальный интернет-портал Президента Республики Беларусь (2015), “Стенограмма встречи с представителями белорусских и зарубежных СМИ”.

${ }^{22}$ Официальный интернет-портал Президента Республики Беларусь (2019), “Послание белорусскому народу и Национальному собранию”.

${ }^{23}$ Официальный интернет-портал Президента Республики Беларусь (2015), “Стенограмма встречи с представителями белорусских и зарубежных СМИ”.

${ }^{24}$ Наша Ніва (2014), “Тозик: Это будет ужасно, если мы потеряем язык”, https:// nn.by/?c=ar\&i=137241\&lang=ru, 25 Мay 2019.

${ }^{25}$ Радыё Свабода (2017), “"Трэба больш размаўляць на беларускай мове», - міністар замежных справаў Беларусі Ўладзімер Макей”, https://www.svaboda.org/a/28556732.html, 25 May 2019.

${ }^{26}$ Толкачева Е. (2018), “Владимир Макей об «ужасных» бутербродах во Дворце независимости, России и белорусском языке”, TUT.BY, https://news.tut.by/economics/606523.html, 25 May 2019.
} 
In line with Lukashenko's narrative, the state representatives tried to use official statistics and present Belarusian language popularity not just as a desire but as the already existing demand in the population, a natural and common thing for Belarusians, which shall not be diminished:

The threat number one - decrease in population due to a low birth rate, 37 percent of respondents think so. At the second place - losing the Belarusian language $[\ldots]^{27}$ (Presidential Aide, October 2014)

[...] we together with a committee of architecture and urban construction recommend having signboards and advertisements in the Belarusian language when it is possible. This is what our population asks for. ${ }^{28}$ (Local Minsk official, May 2015)

[...] Belarusian language is perceived as the most important marker; look at the number of Belarusian language advertisements. It is trendy to speak in Belarusian now. [... $]^{29}$ (Parliamentarian, April 2018)

\subsection{A slightly different look at the Russian language}

The ultimate question that appears when analysing Lukashenko's new narratives on the Belarusian language is, what is the role then assigned to the Russian language, which was dominant before? Analysis of the co-occurrence of codes (overlap or proximity of the codes at the same segment of text) on Russian and Belarusian language perception demonstrated that the Russian language messages and Belarusian language messages frequently overlap or are being discussed immediately one after another.

\footnotetext{
${ }^{27}$ Наша Ніва (2014), “Помощник президента: Белорусы считают главной угрозой для страны утрату белорусского языка”, https://nn.by/?c=ar\&i=137208\&lang=ru, 25 May 2019.

${ }^{28}$ Сухаревич К. (2015), “Мингорисполком рекомендует размещать на исторических зданиях белорусскоязычные вывески и рекламу”, «Минск-Новости», https://minsknews.by/mingorispolkomrekomenduet-razmeshhat-na-istoricheskih-zdaniyah-belorusskoyazyichnyie-vyiveski-i-reklamu/, 25 May 2019.

${ }^{29}$ Наша Ніва (2018), “Чиновники и депутаты - участники круглого стола в унисон выступили за белоруссизацию законодательства”, https://nn.by/?c=ar\&i=207608\&lang=ru, 25 May 2019.
} 
Table 2. Co-occurrence and proximity of codes The values mean a number of codes

\begin{tabular}{|c|c|c|}
\hline $\begin{array}{l}\text { Code / Perception of Belarusian } \\
\text { language }\end{array}$ & $\begin{array}{l}\text { Co-occurrence within } \\
\text { five paragraphs (Bel } \\
\text { language) }\end{array}$ & $\begin{array}{l}\text { Co-occurrence } \\
\text { within same } \\
\text { paragraph (Bel } \\
\text { language) }\end{array}$ \\
\hline \multicolumn{3}{|l|}{ Cultural dimension: } \\
\hline Religion & 2 & 0 \\
\hline Perception of Russian language & 43 & 12 \\
\hline $\begin{array}{l}\text { - Perception of Russian language } \\
\text { / Russian is the "second" mother } \\
\text { language }\end{array}$ & 25 & 6 \\
\hline $\begin{array}{l}\text { - Perception of Russian language } \\
\text { / Russian language needed for } \\
\text { pragmatic reasons }\end{array}$ & 6 & 0 \\
\hline $\begin{array}{l}\text { - Perception of Russian language / } \\
\text { Russian language is the heritage of } \\
\text { three nations }\end{array}$ & 8 & 2 \\
\hline $\begin{array}{l}\text { - Perception of Russian language / } \\
\text { Belarus contributed to the develop- } \\
\text { ment of Russian language }\end{array}$ & 8 & 1 \\
\hline $\begin{array}{l}\text { - Perception of Russian language / } \\
\text { Russian language is not Russia's } \\
\text { language }\end{array}$ & 11 & 1 \\
\hline \multicolumn{3}{|l|}{ Political dimension: } \\
\hline Relations with Ukraine & 2 & 0 \\
\hline Relation to the West & 0 & 0 \\
\hline Relation to Russia & 23 & 0 \\
\hline Economic model & 3 & 0 \\
\hline Political system model & 0 & 0 \\
\hline \multicolumn{3}{|l|}{ Historical dimension: } \\
\hline Relation to BNR & 0 & 0 \\
\hline Statehood & 0 & 0 \\
\hline Relation to GDL & 0 & 0 \\
\hline Relation to USSR & 2 & 0 \\
\hline \multicolumn{3}{|l|}{ Psychological dimension: } \\
\hline Values of the nation & 31 & 1 \\
\hline \multicolumn{3}{|l|}{ Territorial dimension: } \\
\hline Territorial integrity and ethnicity & 26 & 1 \\
\hline
\end{tabular}


Taking into account the co-occurrence results, the analysis of the Belarusian language's narratives alone, excluding the discursive context, is not sufficient to disclose the full picture of the language role prescribed for the identity construction in the official discourse.

The Russian language issue did not vanish from the authorities' agenda (twenty-four instances of this general code), but when speaking about the Belarusian language, against his previous perception, now Lukashenko implies supremacy and importance of the latter. In one of the speeches, he noted that the absolute majority (60 per cent) consider Belarusian as their mother language; ${ }^{30}$ this figure was also backed up in the media by the Informational-Analytical Centre under the Presidential Administration which reported that 48 per cent indicated Belarusian as their mother language while 43 per cent named Russian as their native language. ${ }^{31}$ Furthermore, Lukashenko used to directly compare the "nativeness" of the two languages in terms of importance and clearly ranked the Russian language as the "second" native language (ten instances).

[...] but we will not give away to anyone our second mother Russian language, this is our language. ${ }^{32}$ (January 2015)

The Russian language is our native language. But, maybe, a little bit less native than Belarusian. ${ }^{33}$ (August 2017)

However, such a narration did not mean Lukashenko is giving up the bilingual nation narrative (fourteen instances). Russian continues to be his primary language of communication in public and he constantly demonstrates the Russian language as the native language even when trying to boost the importance of the Belarusian language. Such a combination of narratives serves as a possibility not to exclude from the official "catch-all" identity model the large part of the population for which, as for him, Russian is the primary and often times the only language spoken in daily life.

[...] especially in Russian, which everyone is using at home, in Russian, our language, not rossiyskiy. I insist that this is our language $!^{34}$ (March 2014)

I consider it is a mother tongue, the absolute majority considers it to be a native lan-

\footnotetext{
${ }^{30}$ Официальный интернет-портал Президента Республики Беларусь (2015), “Интервью негосударственным средствам массовой информации”, http://president.gov.by/ru/news_ru/printv/ intervjju-negosudarstvennym-sredstvam-massovoj-informatsii-11882/

${ }^{31}$ Наша Ніва (2019), “ІАЦ: Беларускую мову лічаць роднай 48\% насельніцтва, рускую - 43\%”, https:// nn.by/?c=ar\&i=224979\&lang=ru, 24 May 2019.

${ }^{32}$ Официальный интернет-портал Президента Республики Беларусь (2015), “Стенограмма встречи с представителями белорусских и зарубежных СМИ”.

${ }^{33}$ Еврорадио (2017), “Лукашенко: Русский язык для нас чуть меньше родной, чем белорусский”.

${ }^{34}$ Официальный интернет-портал Президента Республики Беларусь (2014), «Ответы Президента Беларуси Александра Лукашенко на вопросы представителей СМИ 23 марта 2014 г”.
} 
guage, and this is the heritage, the wealth, which we cannot reject. This is our wealth. ${ }^{35}$ (January 2015)

[...] nothing bad if two of our native languages will be close to each other - Russian and Belarusian. We write in this and in that language. ${ }^{36}$ (April 2015)

For me the Belarusian language is my native language. The same as Russian. Maybe I am a bad president in this sense, but the Russian language - it is ours. ${ }^{37}$ (March 2019)

A few important clauses are added by Lukashenko when shaping the role of the Russian language in terms of Belarusians' self-perception. First, Lukashenko implies that the Russian language does not belong exclusively to the Russian Federation. In the quotations above and other communicative events, it is noticeable that Lukashenko is playing with the words rossiyskiy and russkiy, rossiyane and russkie, in order to isolate Russianness as a culture from belonging to the Russian Federation. Second, to strengthen the alienation of the Russian language from Russia, Lukashenko adds Ukraine to the list of national communities, which, in his words, contain different identities but simply share and are used to contribute to the development of the Russian language as cultural heritage (eight instances of two narratives in total).

... we believe (and I reiterated it multiple times) that the Russian language is a common asset of the three brotherly nations - Ukrainians, Belarusians and Russians. And also other peoples that lived with in one country. I want to make it clear once again for those who want to 'privatize' the Russian language. The language is ours. It is neither Russia's, nor Ukraine's. It is ours. ${ }^{38}$ (April 2014)

I gave you an example; I replied to Vladimir Vladimirovich [Putin] when he said: 'Thank you for your approach to the Russian language and so on'. I said: 'Wait, wait, what are you talking about?' 'that Russian language in your country' - wait, the Russian language is our language'. [... $]^{39}$ (January 2015)

Language is something alive, and all together we formed the Russian language, so why we are abandoning it? ${ }^{40}$ (March 2014)

\footnotetext{
${ }^{35}$ Официальный интернет-портал Президента Республики Беларусь (2015), “Стенограмма встречи с представителями белорусских и зарубежных СМИ".

${ }^{36}$ Официальный интернет-портал Президента Республики Беларусь (2015), “Обращение с Посланием к белорусскому народу и Национальному собранию”.

${ }^{37}$ Официальный интернет-портал Президента Республики Беларусь (2019), “Встреча с представителями общественности и экспертного сообщества, белорусских и зарубежных СМИ” “Большой разговор с Президентом".

${ }^{38}$ Официальный интернет-портал Президента Республики Беларусь (2014), “Послание Президента белорусскому народу и Национальному собранию”.

${ }^{39}$ Официальный интернет-портал Президента Республики Беларусь (2015), “Стенограмма встречи с представителями белорусских и зарубежных СМИ".

${ }^{40}$ Официальный интернет-портал Президента Республики Беларусь (2019), “Встреча с представителями общественности и экспертного сообщества, белорусских и зарубежных СМИ” “Большой разговор с Президентом".
} 
Such narratives help to address potential threats to national unity and build greater resilience of the segment of the population which speaks only in Russian and is more vulnerable to Russian informational influence. And Russian informational influence is extremely strong in Belarus; it is not just prevailing in the country's media space; it successfully penetrates the public perceptions. The 2015 IISEPS poll indicated that only 18.7 per cent would fight against Russia's intention to annex Belarus while 52.8 per cent were ready to adjust, and another 12.1 per cent would welcome this. ${ }^{41}$ Besides, the polls demonstrated that despite the rather distant position of Belarus authorities in relation to the war in Ukraine and the annexation of Crimea by Russia, Belarusians tend to interpret these events as Russian media portrays them. For instance, in June 2015, only 15.2 per cent of Belarusians negatively perceived the so-called "Russian World" idea, while 38.9 perceived it positively; a little more than 20 per cent perceived Crimea's annexation as an occupation, while the vast majority (62.3) perceived it as the "restitution of historical justice," and only 10.5 per cent perceived the war in the Donbas region of Ukraine as Russian aggression. ${ }^{42}$

\subsection{Depoliticization of the Belarusian language choice}

One of the first steps towards the construction of a new social representation in relation to the Belarusian language was the need to depoliticize this phenomenon by the authorities. The Belarusian language used to be generally perceived as a symbol of political opposition and a protest vote. Considering that in early 2014 the majority of Belarusian-speaking opposition still considered ploshcha (street protest) as the only way to challenge Lukashenko's rule, Lukashenko put major focus on the antirevolutionary manner of the language issue with consistent reference to the 1995 referendum and "people's will". At the same time, Lukashenko often referred to the war in Ukraine to warn against the enforcement of the Belarusian or Russian language over the people. He even placed the origin of this conflict to the language policy there. Undoubtedly, such an interpretation and frequent reference to the conflict was useful for the authorities because it attempted to undermine the rhetoric of opposition and more specifically its role in the Belarusian language promo-

\footnotetext{
${ }^{41}$ Независимый институт социально-экономических и политических исследований (2015), “Национальный опрос 2-12 июня 2015 г., http://www.old.iiseps.org/data15-61.html, 28 December 2015.

${ }^{42}$ Ibidem.
} 
tion. It also helped Lukashenko to draw a contrast and position himself as the moderate decision maker and guarantor of peace and political stability.

We should not do anything artificially. You will push away half of the people. [...] Nothing revolutionary. A professional approach and peace are the most important. Mova [the Belarusian language] is not for revolutions. ${ }^{43}$ (January 2014)

Nevertheless, Lukashenko did not exclude the possibility that the Belarusian language needs more development or support. In order not to contradict his position against artificialness Lukashenko uses careful, not obliging proposals, and does not speak about the direct language support, but uses personal examples and references to his youngest son to hint at the importance of the Belarusian language for the future generation of the nation.

Okay, almost all of us speak Russian. But in the Belarusian language, let's say openly, at home, daily, we speak it less. So, maybe, we should add an extra hour for the Belarusian language, not English, at school? ${ }^{44}$ (September 2014)

My kid is growing - I want him to know Belarusian as well as Russian. ${ }^{45}$ (January 2015)

To sum up the role of languages in Lukashenko's discourse, the positive shift towards the Belarusian language is observable. As the soft-Belarusization term implies, there are no hard lines in the president's discourse and the bilingual nation narrative, as well as the importance of preserving the Russian language, is maintained. Two of the top three narratives that create a social representation in relation to Belarus' language are built on a bilingual nation idea (see table below). However, as discussed in Section 2.2, the authorities imposed important reservations on the Russian language use by Belarusians to distance themselves from Russia as a political entity.

Table 3. Total frequency of subcodes on Russian and Belarusian language perceptions

\begin{tabular}{|lll|}
\hline \multicolumn{1}{|c|}{ Subcodes } & \multicolumn{1}{c|}{ Frequency } & \multicolumn{1}{c|}{ Percentage } \\
\hline Belarus is a bilingual nation & 14 & 20.59 \\
\hline $\begin{array}{l}\text { Belarusian is a distinctive feature of the } \\
\text { Belarusian nation }\end{array}$ & 12 & 17.65 \\
\hline Russian is the "second" mother language & 10 & 14.71 \\
\hline Language cannot be enforced & 6 & 8.82 \\
\hline
\end{tabular}

\footnotetext{
${ }^{43}$ Официальный интернет-портал Президента Республики Беларусь (2014), “Встреча с руководителями крупнейших белорусских СМИ".

${ }^{44}$ Официальный интернет-портал Президента Республики Беларусь (2014), “Встреча с членами Совета Палаты представителей Национального собрания".

${ }^{45}$ Официальный интернет-портал Президента Республики Беларусь (2015), “Стенограмма встречи с представителями белорусских и зарубежных СМИ”.
} 


\begin{tabular}{|lll|}
\hline $\begin{array}{l}\text { The Belarusian language needs develop- } \\
\text { ment }\end{array}$ & 5 & 7.35 \\
\hline [Lukashenko speaks in Belarusian] & 5 & 7.35 \\
\hline $\begin{array}{l}\text { The Russian language is not Russia's } \\
\text { property }\end{array}$ & 4 & 5.88 \\
\hline $\begin{array}{l}\text { The Russian language is the heritage of } \\
\text { three nations }\end{array}$ & 4 & 5.88 \\
\hline $\begin{array}{l}\text { Belarus contributed to the development of } \\
\text { Russian language }\end{array}$ & 4 & 5.88 \\
\hline $\begin{array}{l}\text { The Russian language is needed for prag- } \\
\text { matic reasons }\end{array}$ & 3 & 4.41 \\
\hline $\begin{array}{l}\text { Belarusian does not require support or } \\
\text { protection }\end{array}$ & 1 & 1.47 \\
\hline TOTAL & 68 & 100.00 \\
\hline
\end{tabular}

\section{Interdiscursivity:}

Political, Historical, Territorial and Psychological Dimensions, and the Language Discourse

Lukashenko's narratives on the Belarusian language cannot be perceived excluding the discursive context of his communicative events. This section will check the interdiscursivity between the new language discourse and the main narratives of the other four dimensions: political, historical, territorial and psychological, which prevail in the sample of communicative events.

As demonstrated in Table 2, when speaking about the language Lukashenko often touched on the following three topics/codes in his communication: relations with Russia, values and territorial integrity. Lukashenko's discourse on the Belarusian language rarely interacted with historical narratives, although there are numerous practical changes in this regard running in parallel with the soft-Belarusization trend, including the replacement of St George ribbons with Belarusian national ribbons and changing Russian-style commemorative events such as the "Immortal Regiment" parade during the 9 May celebrations with Belarusian analogues.

Moving to the political dimension, the discussion around relations with Russia is present due to the interconnection of both codes on Russian language and Belarusian language perception, and due to the close relations between the countries. It is generally known that Russia frequently accuses so-called "near abroad" countries of discriminating against Russian speakers, thus stressing that "brotherly" relations may look inevitable when promoting the Belarusian language over Russian, particularly taking into consideration the number of 
accusations and frustrations appearing in imperialistically-minded Russian media segments after the soft-Belarusization trend emergence. Overall, three well-known narratives on Russia by Lukashenko were maintained: first, that Belarus and Russia are brotherly countries (Lukashenko separates "Russians" as an ethnic group from rossiyane as citizens of Russia); second, both share common history and roots; and the third, claiming that Russia is the main strategic partner despite the several crises in the bilateral relations within the time frame of analysis.

However, similarly to the Russian language perception narratives, there are certain reservations in the description of the ties between the two countries. Despite being "brothers" (see Table 4 below), Lukashenko claims distinct identities by consistently pointing to Belarus' territorial integrity and sovereignty. After the 2018-2019 economic tensions with Russia, this time marked by a strong political agenda and the Kremlin's pressure for deeper integration in exchange for previous economic benefits, Lukashenko clearly denied any chance for political unification or other form of factual unity with the Russian Federation. He claimed that the vast majority of Belarusian society will be against that, which in fact is true given the results of independent polls. ${ }^{46}$ On top of that, Lukashenko tries to keep the countries' relations (at least in the discourse) primarily focused on the economics agenda rather than political or military cooperation, and sees the current integration direction as primarily economics-driven, based on the equality of partners.

Table 4. Frequency of subcodes on relations with Russia

\begin{tabular}{|lll|}
\hline Subcodes & Frequency & Percentage \\
\hline Russia and Belarus are brotherly nations & 14 & 30.43 \\
\hline Cooperation with Russia is primarily economic & 8 & 17.39 \\
\hline Belarusians and Russians are different and sovereign & 7 & 15.22 \\
\hline Russia is a strategic partner & 5 & 10.87 \\
\hline Integration projects should be based on equality & 5 & 10.87 \\
\hline Common history with Russia & 4 & 8.70 \\
\hline There is a group in Russia that wants to threaten Belarus & 3 & 6.52 \\
\hline TOTAL & 46 & 100.00 \\
\hline
\end{tabular}

Lukashenko was also consistently attributing a set of values to the Belarusian people. Amid events in Ukraine, organization of the controversial Zapad 2017 exercise and tensions in bilateral relations with Russia, the peacefulness

\footnotetext{
${ }^{46}$ Naviny.by (2017), “Большинство белорусов между союзом с ЕС и РФ выбирают Россию”, https:// naviny.by/new/20170522/1495429692-bolshinstvo-belorusov-mezhdu-soyuzom-s-es-i-rf-vybirayut-rossiyu, 22 May 2017.
} 
narrative was dominant. This narrative captured both domestic peace (peace and accord within the society) and external peacefulness portraying Belarus as defence-oriented and peacekeeping country. Therefore, it can be assumed that the peacefulness value was dominant as it was addressed to both a domestic audience to prevent division and protest, and to external actors to increase Minsk's role in the region as a neutral mediator in regional conflict resolution.

The values promoted in Lukashenko's discourse are often accompanied and connected to a territorial dimension, one of the core elements of the "civic" identity model. Narratives on the territory are primarily aimed at stressing the country's independence, as well as an internal territorial integrity, excluding any potential differences among different regions of the country. Ethnicity, belonging to a particular ethnic group (similar to religion) does not play any role in Lukashenko's identity discourse. Despite higher focus put on the Belarusian language, the authorities continue to maintain the core element of the civic identity model - the idea that territory and citizenship is one of the major markers of the Belarusian identity.

\section{Context: \\ From the New Language Discourse to New Social Practices}

Considering the particularities of Belarus' political management, the new narrative and depoliticization of the Belarusian language served as certain guidance for state officials. Besides becoming more open to the Belarusian language perception in the public and repeating Lukashenko's ideas as described in Section 2.1, officials also began to document the new role prescribed for the language. In the Information Security Concept of Belarus, the Security Council identified the Belarusian language as a guarantor of the state's humanitarian security. In line with Lukashenko's analysed discourse, the Secretary-General of the Council later clarified the need to popularize the language because it is one of the core elements of the national identity. ${ }^{47}$

The discourse influenced public actions. First of all, because of the official rhetoric, civil society immediately noticed that people became less afraid to use the Belarusian language, learn or teach it, or join respective organizations such as the Belarusian Language Society, ${ }^{48}$ the incumbent leader of

\footnotetext{
${ }^{47}$ Шрайбман А. (2019), “Госсекретарь Совбеза: Зачем чиновнику согласовывать с начальством появление в СМИ?”, ТUT.BY, https://news.tut.by/economics/630845.html, 24 May 2019.

48 Щербаков 3. (2015), “Сегодня отмечается Международный день родного языка”, БелаПАН, http:// belapan.com/archive/2015/02/21/760572_760573/, 23 February 2015.
} 
which - Alena Anisim - was even elevated to the national parliament in 2016. Law enforcement and the authorities did not interfere and allowed the civic and other initiatives to develop, for instance, legal registration of popular Belarusian language courses called Mova Nanova. ${ }^{49}$ Within the last five years, merchandise promoting Belarusian cultural symbols and phrases in the Belarusian language have become a popular trend and even a profitable business opportunity. The authorities try to walk in line with this trend and even demonstrate their support. That, for example, relates to the popularization of national symbols, particularly the vyshyvanka (the embroidered shirt in national costume). Vyshyvankas used to be promoted in public by civil society initiatives, such as the Vyshyvanka Day festival, which was organized by Art Siadziba, a hub promoting Belarusian national symbols and language, and the Belarusian Union of Artists. ${ }^{50}$ However, this initiative was soon "hijacked" by pro-government state-sponsored organizations such as the Belarusian Republican Youth Union (BRSM). ${ }^{51}$

It is important to stress that there is a clear end-list of beneficiaries of soft-Belarusization, as well as invisible boundaries as to what extent the language could be promoted in practice. The authorities use all available means to prevent political actors, especially the political opposition, from stepping into this field of identity building. For example, citing "legal inconsistency" the Ministry of Justice and the National Centre of Legislation and Legal Research opposed a draft bill on state support for the Belarusian language proposed by opposition parliamentarian Alena Anisim. ${ }^{52}$ Prominent opposition activists have raised the Belarusian language issue, demanding state support in legislation and other fields for years. Despite the change in the discourse, any public activity unacceptable to the authorities, such as signature collection under petitions, is still prosecuted. For instance, the petition drive initiated by former "Young Front" leader and political prisoner Zmitser Dashkevich, aimed at supporting Belarusian language education, resulted in the government ignoring this and issuing heavy fines to activists..$^{53}$

\footnotetext{
${ }^{49}$ Еврорадио (2014), “Курсы 'Мова Нанова’ получили государственную регистрацию”, http://euroradio.fm/ru/kursy-mova-nanova-poluchili-gosudarstvennuyu-registraciyu, 22 December 2015.

50 Занько Н. (2014), “«День вышиванки»: полный аншлаг, мыло с «Погоней» и вышитые сережки”, Комсомольская правда Беларусь, https://www.kp.by/daily/26320.7/3199168/, 23 May 2019.

${ }^{51}$ БРСМ (2016), “Молодежный арт-парад откроет «День вышиванки» в Минске”, http://brsm.by/ news/den-vy-shivanki-v-minske/, 23 Мау 2019.

52 Глод У. (2019), “Улады заблякавалі законапраект аб падтрымцы беларускай мовы”, Радыё Свабода, https://www.svaboda.org/a/29937628.htm, 23 May 2019.

${ }^{53}$ Naviny.by (2018), “В Беларуси штрафуют за сбор подписей в поддержку образования на родном языке”, https://naviny.by/new/20180313/1520962624-v-belarusi-shtrafuyut-za-sbor-podpisey-v-podderzhku-obrazovaniya-na-rodnom, 23 May 2019.
} 


\section{Conclusions}

The results of the discourse analysis of Lukashenko's communicative events demonstrated the existence of substantial - and most important - sustainable change in the Belarusian language perception. The new social representation, the new set of ideas, has been purposefully introduced to strengthen the self-identification of Belarusians. Both Lukashenko and other officials began to perceive and portray the Belarusian language as a distinctive feature of the Belarusianness, the primary element that distinguishes the nation and drags it further from Russian cultural and linguistic influence. The creation of new social representation in the cultural dimension required the authorities to change the previous perception of the Belarusian language and carefully adjust their earlier narratives on bilingualism and the Russian language's role in order not to exclude the Russian-speaking part of the population and avoid Russia's criticism.

The reconstruction of the social representation of the Belarusian language implied changes to the behaviour of government officials, civil society and even the public, but that neither changed the authorities' attitude towards the political opposition, which has been promoting the Belarusian language for decades, nor abandoned repressive mechanisms in cases when the language issue could bring political dividends for the opponent. The opposition's advocacy efforts, even when they are in line with new social representation and are not aimed at challenging Lukashenko's rule, are immediately cut off by the authorities in order to exclude political actors from identity formation processes.

The authorities attempt to keep the Belarusization process as "soft" as possible both in terms of policy initiatives and politicization of the language issue. Therefore, given the limitations imposed on the political opposition and authorities' hesitation to adopt practical measures in support of the Belarusian language, the civil society, within the control of the authorities' framework of activities, remains and likely will remain the only major facilitator of new social practices and the growing popularity of Belarusian language among the public. Without any major changes in the geopolitical field and in relations with Russia, the activities of the official state representatives will likely continue to be limited to the local-level language popularization.

As the empirical part of this article demonstrates, the major changes took place only with regards to the Belarusian language perception but small changes and reservations made to other narratives in this context also convey 
new meanings. The authorities have added changes to the previous identity model, and it becomes a bit closer to the opposition's ethnocultural perception of Belarusianness. Together with the changing cultural dimension, pursuing the same goal to diminish Russian cultural and linguistic influence, the authorities slightly modified and several other narratives in the political dimension to impose additional limitations on ties with Russia. But the latter and other discursive changes in other than language elements are very limited and are not sufficient to conclude that the authorities completely changed other identity dimensions and move towards ethnocultural identity in the nearest future.

Nevertheless, the first fruits of the soft-Belarusization trend are visible within society and the sustainability of the trend indicates that this is a long-term strategy. If this approach is continued, it would result in a more consolidated identity shared by younger generations, for whom the Belarusian language could become the core element of self-identification, not necessarily associated with the political choice as it appeared to previous generations.

May 2019

\section{Annex. Analysed communicative events}

1. Официальный интернет-портал Президента Республики Беларусь (2014), “Встреча с руководителями крупнейших белорусских СМИ", http://president.gov. by/ru/news_ru/printv/vstrecha-s-rukovoditeljami-belorusskix-smi-7880/

2. Официальный интернет-портал Президента Республики Беларусь (2014), “Ответы Президента Беларуси Александра Лукашенко на вопросы представителей СМИ 23 марта 2014 r., http://president.gov.by/ru/news_ru/printv/otvety-prezidenta-respublikibelarus-aleksandra-lukashenko-na-voprosy-predstavitelej-smi-23-marta-2014-g-8342/

3. Официальный интернет-портал Президента Республики Беларусь (2014), “Послание Президента белорусскому народу и Национальному собранию”, http:// president.gov.by/ru/news_ru/printv/aleksandr-lukashenko-obraschaetsja-s-ezhegodnym-poslaniem-k-belorusskomu-narodu-i-natsionalnomu-sobraniju-8549/

4. БелТА (2014), “Выступление Лукашенко на торжественном собрании в честь Дня Независимости и 70-летия освобождения Беларуси”, https://www.belta.by/president/view/vystuplenie-lukashenko-na-torzhestvennom-sobranii-v-chest-dnja-nezavisimosti-i-70-letija-osvobozhdenija--48706-2014

5. Официальный интернет-портал Президента Республики Беларусь (2014), "Встреча с членами Совета Палаты представителей Национального собрания", http://president.gov.by/ru/news_ru/printv/vstrecha-s-chlenami-soveta-palaty-predstavitelej-natsionalnogo-sobranija-9884/ 
6. Официальный интернет-портал Президента Республики Беларусь (2014), “Прессконференция Президента Республики Беларусь А.Г.Лукашенко журналистам российских региональных средств массовой информации", http://president.gov.by/ ru/news_ru/printv/press-konferentsija-prezidenta-respubliki-belarus-aglukashenkozhurnalistam-rossijskix-regionalnyx-sredstv-10025/

7. Официальный интернет-портал Президента Республики Беларусь (2015), “42-ой съезд Белорусского республиканского союза молодежи”, http://president.gov.by/ru/ news_ru/printv/42-oj-sjezd-belorusskogo-respublikanskogo-sojuza-molodezhi-10682/

8. Официальный интернет-портал Президента Республики Беларусь (2015), “Стенограмма встречи с представителями белорусских и зарубежных СМИ", http://president.gov.by/ru/news_ru/printv/stenogramma-vstrechi-s-predstaviteljamibelorusskix-i-zarubezhnyx-smi-10760/

9. Официальный интернет-портал Президента Республики Беларусь (2015), “Интервью медиахолдингу 〈Блумберг”, http://president.gov.by/ru/news_ru/printv/ intervjju-mediaxoldingu-blumberg-11120/

10. Официальный интернет-портал Президента Республики Беларусь (2015), “Обращение с Посланием к белорусскому народу и Национальному собранию”, http://president.gov.by/ru/news_ru/printv/obraschenie-s-poslaniem-k-belorusskomunarodu-i-natsionalnomu-sobraniju-11301/

11. Официальный интернет-портал Президента Республики Беларусь (2015), “Интервью негосударственным средствам массовой информации", http://president.gov.by/ru/news_ru/printv/intervjju-negosudarstvennym-sredstvam-massovojinformatsii-11882/

12. Официальный интернет-портал Президента Республики Беларусь (2017), "Послание белорусскому народу и Национальному собранию", http://president. gov.by/ru/news_ru/printv/ezhegodnoe-poslanie-k-belorusskomu-narodu-i-natsionalnomu-sobraniju-16059/

13. БелТА (2017), “Лукашенко: пройдя сквозь испытания, белорусы заслужили право жить на свободной земле”, https://www.belta.by/president/view/lukashenko-projdjaskvoz-ispytanija-belorusy-zasluzhili-pravo-zhit-na-svobodnoj-zemle-255445-2017/

14. TUT.BY (2017), “Лукашенко: Нам не нужны войны, революции, спекуляция на демократии и правах человека”, https://news.tut.by/economics/549684.html

15. TUT.BY (2017), “Лукашенко: Беларусь не намерена отказываться от русского языка, но будет поднимать и белорусский”, https://news.tut.by/society/551015.html

16. Радыё Свабода (2017), “Лукашэнка: «Мая душа - у расейскай мове», «расейская мова - дабро для нас»”, https://www.svaboda.org/a/28674294.html

17. Еврорадио (2017), “Лукашенко: Русский язык для нас чуть меньше родной, чем белорусский”, https://euroradio.fm/ru/lukashenko-russkiy-yazyk-dlya-nas-chut-menshe-rodnoy-chem-belorusskiy

18. Официальный интернет-портал Президента Республики Беларусь (2017), “Віншаванне з Днём беларускага пісьменства”, http://president.gov.by/ru/news_ru/ printv/vinshavanne-z-dnem-belaruskaga-pismenstva-16993/ 
19. БелТА (2017), “Всебелорусский съезд 1917 года продемонстрировал ценности, значимые до настоящего дня - Лукашенко", https://www.belta.by/president/view/ vsebelorusskij-sjezd-1917-goda-prodemonstriroval-tsennosti-znachimye-do-nastojaschego-dnja-lukashenko-278486-2017/

20. БелТА (2018), “Лукашенко: в современном быстро меняющемся мире белорусам важно не потерять свою идентичность”, https://www.belta.by/president/view/ lukashenko-v-sovremennom-bystro-menjajuschemsja-mire-belorusam-vazhno-nepoterjat-svoju-identichnost-284220-2018/

21. БелТА (2018), “Лукашенко о БНР: необходимо знать правду о тех событиях, но гордиться ими не стоит”, https://www.belta.by/president/view/lukashenko-o-bnr-neobhodimo-znat-pravdu-o-teh-sobytijah-no-gorditsja-imi-ne-stoit-294905-2018/

22. БелТА (2018), “Лукашенко: белорусам еще предстоит понять роль БНР”, https:// www.belta.by/president/view/lukashenko-belorusam-esche-predstoit-ponjat-rolbnr-298008-2018/

23. БелТА (2018), “Лукашенко о расширении использования белорусского языка: давайте будем делать все спокойно, шаг за шагом”, https:/www.belta.by/president/ view/lukashenko-o-rasshirenii-ispolzovanija-belorusskogo-jazyka-davajte-budem-delat-vse-spokojno-shag-za-300001-2018/

24. БелТА (2018), “Интересы Беларуси и России никогда не противоречат друг другу - Лукашенко”, https://www.belta.by/president/view/interesy-belarusi-i-rossii-nikogdane-protivorechat-drug-drugu-lukashenko-315854-2018/

25. Наша Ніва (2019), “На церемонии вручения премии «За духовное возрождение» Лукашенкочасть речипроизнеспо-белорусски",https://nn.by/?c=ar\&i=223366\&lang=ru

26. БелТА (2019), “Лукашенко утвердил Концепцию информационной безопасности Беларуси”, https://www.belta.by/president/view/lukashenko-utverdil-kontseptsiju-informatsionnoj-bezopasnosti-belarusi-340423-2019/

27. Радыё Свабода (2019), “Лукашэнка абурыўся беларускамоўнымі дарожнымі знакамі", https://www.svaboda.org/a/29891311.html

28. Официальный интернет-портал Президента Республики Беларусь (2019), “Встреча с представителями общественности и экспертного сообщества, белорусских и зарубежных СМИ 'Большой разговор с Президентом', http://president.gov.by/ru/ news_ru/printv/vstrecha-s-predstaviteljami-obschestvennosti-i-ekspertnogo-soobschestva-belorusskix-i-zarubezhnyx-smi-20590/

29. Официальный интернет-портал Президента Республики Беларусь (2019), "Послание белорусскому народу и Национальному собранию", http://president. gov.by/ru/news_ru/printv/poslanie-belorusskomu-narodu-i-natsionalnomu-sobraniju-20903/ 